\title{
HUBUNGAN CAIRAN INFUS DAN LOKASI PEMASANGAN INFUS DENGAN KEJADIAN FLEBITIS DI RUMAH SAKIT DKT \\ BANDAR LAMPUNG
}

$$
\text { Marlina Silviawaty }{ }^{1} \text {, Dian Utama Pratiwi Putri }{ }^{2}
$$

${ }^{1}$ Mahasiswa Prodi Magister Kesehatan Masyarakat Universitas Mitra Indonesia Email : silviawatymarlina@gmail.com

${ }^{2}$ Dosen Prodi Magister Kesehatan Masyarakat Universitas Mitra Indonesia Email : dian@umitra.ac.id

\section{ABSTRACT: CORELATION BETWEEN INFUSION FLUID USE AND LOCATION OF INFUSION WITH PHLEBITIS OCCURRENCE IN DKT HOSPITAL BANDAR}

Background:Phlebitis is venous inflammation caused by either chemical or mechanical irritation. The incidence of phlebitis in 2019 DKT Hospital is 1.8\% cases while the indicator limit for phlebitis is $1.5 \%$.

Purpose:Determine the corelation between infusion fluid use and location of infusion with phlebitis occurrence in DKT Hospital Bandar Lampung 2020

Methods:The type of research is a quantitative study with a case control approach. The study population is 55 patients with phlebitis as a sample cases and 55 patients without phlebitis as control patients. Dats Analysis using univariate analysis and bivariate.

Results :It shows the relation between the type of infusion fluid ( $p v=0,000$; $O R=8.5)$ and location of infusion ( $p v=0.002 ; O R=3.5)$ with phlebitis occurrence in DKT Hospital Bandar Lampung.

Conclusion:From the results of the study it was suggested perfecting the SOP and disseminating information on hypertonic infusion fluid and monitoring it regularly and continuously

Keywords: Phlebitis, type of fluid, location of infusion 


\section{INTISARI:HUBUNGAN CAIRAN INFUS DAN LOKASI PEMASANGAN INFUS DENGAN KEJADIAN FLEBITIS DI RUMAH SAKIT DKT BANDAR LAMPUNG}

Latar Belakang:Flebitisadalah inflamasi vena yang disebabkan baik iritasi kimia atau mekanik. Angka kejadian flebitis di RS DKT Tahun 2019 adalah 1,8\% kasus flebitis sedangkan batas indikator flebitis adalah $1,5 \%$.

Tujuan: Untuk mengetahui hubungan antara penggunaan cairan infus dan lokasi pemasangan infus dengan kejadian flebitis di RS DKT Bandar Lampung Tahun 2020.

Metode:Jenis penelitian adalah kuantitatif dengan pendekatan case control. Populasi penelitian ini adalah 55 pasien flebitis sebagai sampel kasus dan 55 pasien yang tidak flebitis sebagai pasien kontrol.Analisis menggunakan analisis univariat, bivariat (chi square).

Hasil: Hasil penelitian menunjukkan ada hubungan jenis cairan infus ( $p v=0,000$; $\mathrm{OR}=8,5)$ dan lokasi pemasangan infus $(p v=0,002 ; \mathrm{OR}=3,5)$ dengan kejadian flebitis di Rumah Sakit DKT Bandar Lampung tahun 2020.

Kesimpulan: Dari hasil penelitian disarankan bahwa Rumah Sakit DKT untuk menyempurnakan SPO dan sosialisasi tentang pemberian cairan infus hipertonis dan monitoring secara berkala dan berkesinambungan.

Kata kunci: Kejadian flebitis, jenis cairan infus dan lokasi pemasangan infus

\section{Pendahuluan}

Flebitisadalah inflamasi vena yang disebabkan baik oleh iritasi kimia maupun mekanik (Smeltzer dan Bare, 2002). Flebitis merupakan salah satu infeksi yang didapat di Rumah Sakit yang disebut dengan Infeksi Terkait Layanan Kesehatanatau beberapa waktu yang lalu disebut dengan infeksi nosokomial (Kemenkes RI, 2017).

Menurut dataWHO, prevalensi Infeksi Terkait Layanan Kesehatandi negara majubervariasi antara 3,5\% dan $12 \%$, sedangkan di negara berkembang antara $5,7 \%$ dan $19,1 \%$. Data Kemenkes RI Tahun 2013, jumlah kejadian flebitis di Indonesia masih tinggi, sebanyak $50,11 \%$ untuk Rumah Sakit pemerintah, dan 32,70\% untuk Rumah Sakit Swasta (Rizky, 2016).

$$
\text { Di provinsi Lampung, }
$$

persentase kejadian flebitis di Rumah Sakit Abdoel Moeloek pada tahun 2017 berjumlah 9,39\%. Menurut data Dinas Kesehatan Provinsi Lampung tahun 2017, di RS Graha HusadaBandar Lampung, ditemukan 30 kejadian flebitis dengan insiden rate 11,2 permil pada bulan januari, dan 28 kejadian flebitis dengan insiden rate 12,2 permil (Hermawan, Junika, Nadeak, 2018).

Faktor risiko terjadinya flebitis adalah jenis materi kanula, iritasi kimia yang berasal dari substansi tambahan dan obatobatan yang diberikan secara intravena (misalnya antibiotik) dan posisi anatomis kanula (Potter \&Perry, 2010). Insiden flebitis meningkat sesuai dengan lamanya pemasangan jalur intravena, komposisi cairan atau obat yang diinfuskan (terutama $\mathrm{pH}$ dan tonisitasnya), ukuran dan tempat kanula yang dimasukkan, pemasangan jalur IV yang tidak sesuai, dan masuknya

Marlina Silviawaty ${ }^{1}$, Dian Utama Pratiwi Putri ${ }^{2}$

${ }^{1}$ Mahasiswa Prodi Magister Kesehatan Masyarakat UMI. Email : silviawatymarlina@gmail.com

${ }^{2}$ Dosen Prodi Magister Kesehatan Masyarakat UMI. Email : dian@umitra.ac.id 
mikroorganisme pada saat penusukan(Smeltzer dan Bare, 2002).

Flebitis dapat berdampak bagi pasien, maupun bagi Rumah Sakit. Flebitis dapat menjadi berbahaya karena bekuan darah (tromboflebitis)dapat terbentukdan pada beberapa kasus dapat menyebabkan emboli. (Potter\&Perry, 2010). Sedangkan bagi Rumah Sakit, hal ini akan menambah beban kerja petugas kesehatan. Infeksi meningkatkan morbiditas dan mortalitas, memperpanjang rawat inap, menyebabkan hilangnya waktu kerja dan meningkatkan biaya perawatan (Sjamsuhidajat, 2013).

Upaya-upaya yang dilakukan untuk menemukan terjadinya flebitis adalah dengan langkahlangkah surveilans, yaitu perencanaan, pengumpulan data, analisis, interpretasi, pelaporan dan evaluasi terhadap flebitis di Rumah Sakit. (Kemenkes RI, 2017).

Menurut penelitian Yuniati (2018), membuktikan adanya keterkaitan antara jenis cairan dan lokasi pemasangan kateter intravena dengan kejadian flebitis. Demikian juga hasil penelitian Wahyu (2016) menyebutkan adanya hubungan jenis cairan intravena dengan kejadian flebitis. Berdasarkan data tim Pencegahan dan Pengendalian Infeksi (PPI) Rumah Sakit DKT Bandar Lampung, menunjukan bahwa angka kejadian flebitis di RS DKT pada periode 2017-2019 masih bervariasi, pada tahun 2017 sebesar2,4\%, Tahun 2018 turun menjadi 1,05\% dan di tahun 2019 mengalami peningkatan menjadi1,8\% kasus. Dengan batas indikator flebitis sebesar $1,5 \%$ menunjukkan kejadian flebitis di
Rumah Sakit DKT Bandar Lampung masih perlu menjadi perhatian.

Tujuan penelitian adalah untuk mengetahui hubungan antara penggunaan cairan infus dan lokasi pemasangan infus dengan kejadian flebitis di RS DKT Bandar Lampung Tahun 2020

\section{Metode Penelitian}

Jenis penelitian adalah kuantitatif desain analitik dengan pendekatan case control. Penelitian ini telah dilakukan pada tanggal 17Februari- 31Maret tahun 2020 di RS DKT Bandar Lampung. Populasi penelitian ini adalah 55 pasien flebitis sebagai sampel kasus dan 55 pasien yang tidak flebitis sebagai pasien kontrol

Kriteria inklusi pada kelompok kasusdalam penelitian ini adalah pasien rawat inap, terpasang infus dan terdiagnosa flebitis dan rekam medis lengkap dan jelas. Adapun eksklusinya adalah pasien penderita gagal ginjal kronik dengan hemodialisa. Pengumpulan data ini, dilakukan dengan penelusuran rekam medis menggunakan lembar checklist dan observasi kepada perawat tentang SPO pemasangan infus dan catatan pemberian infus. Tahapan dilakukan melalui checklist data rekam medis, observasi 10 perawat dalam menjalankan SPO pemasangan infus, dan observasi pencatatan infus parenteral yang terdiri dari 11 item operasional.

Pengolahan data dalam penelitian ini ada 4 yaitu Editing Data, Coding, Processing, Cleaning dan analisis data menggunakan program komputer yang dilakukan 2 tahap yaitu analisis univariat dan bivariat menggunakan uji Chi Square. Pengolahan data dengan aplikasi SPSS versi 20.

Marlina Silviawaty ${ }^{1}$, Dian Utama Pratiwi Putri ${ }^{2}$

${ }^{1}$ Mahasiswa Prodi Magister Kesehatan Masyarakat UMI. Email : silviawatymarlina@gmail.com

${ }^{2}$ Dosen Prodi Magister Kesehatan Masyarakat UMI. Email : dian@umitra.ac.id 


\section{Hasil Univariat}

Distribusi Frekuensi Responden berdasarkan Jenis Cairan Infus dan Lokasi Pemasangan Infus.

\begin{tabular}{lcccc}
\hline \multirow{2}{*}{ Variabel } & \multicolumn{5}{c}{ Kejadian Flebitis } \\
\cline { 2 - 5 } & \multicolumn{2}{c}{ Kasus } & \multicolumn{3}{c}{ Kontrol } \\
\cline { 2 - 5 } & $\mathrm{n}$ & $\%$ & $\mathrm{n}$ & $\%$ \\
\hline Jenis Cairan Infus & & & & 7,3 \\
Berisiko & 22 & 40,0 & 4 & 92,7 \\
Tidak Berisiko & 33 & 60,0 & 51 & \\
\hline Lokasi & & & & 34,5 \\
Pemasangan & 36 & 65,5 & 19 & 65,5 \\
Berisiko & 19 & 34,5 & 36 & 100 \\
Tidak Berisiko & 55 & 100 & 55 & \\
\hline Total & & & &
\end{tabular}

Bivariat

Hubungan Jenis Cairan Infus dan Lokasi Pemasangan Infus dengan Kejadian Flebitisdi Rumah Sakit DKT Bandar Lampung Tahun 2020.

Variabel Kejadian Flebitis $p$ value $\quad O R$

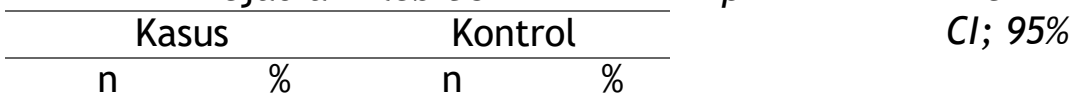

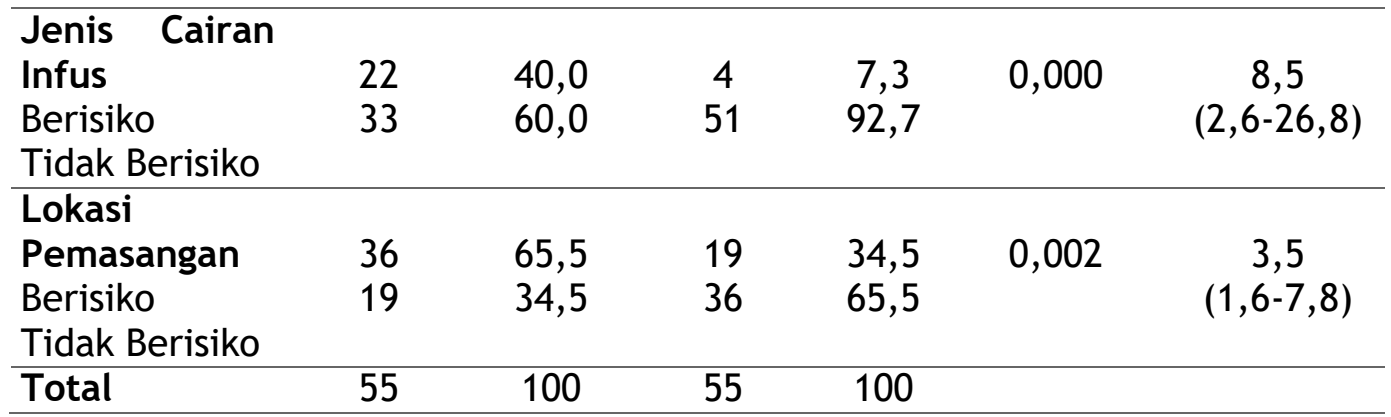

Marlina Silviawaty ${ }^{1}$, Dian Utama Pratiwi Putri ${ }^{2}$

${ }^{1}$ Mahasiswa Prodi Magister Kesehatan Masyarakat UMI. Email : silviawatymarlina@gmail.com

${ }^{2}$ Dosen Prodi Magister Kesehatan Masyarakat UMI. Email : dian@umitra.ac.id 


\section{Pembahasan}

\section{a. Jenis Cairan Infus}

Pemberian cairan intravena adalah pemberian sejumlah cairan ke dalam tubuh masuk ke pembuluh darah vena untuk memperbaiki atau mencegah gangguan cairan dan elektrolit, darah, maupun nutrisi (Perry \&Potter, 2006). Pemberian cairan intravena disesuaikan dengan kondisi kehilangan cairan pada klien, seberapa besar cairan tubuh yang hilang. Pemberian cairan intravena merupakansalah satu tindakan intravena. Cairan isotonik merupakan cairan yang secara fisiologis sesuai dengan cairan tubuh, cairan ini di gunakan untuk mengganti serta mempertahankan cairan tubuh. Osmolaritas (tingkat kepekatan) cairannya mendekati serum (bagian cair dari komponen darah), sehingga terus berada di dalam pembuluh darah. Bermanfaat pada pasien yang mengalami hipovolemi.

Cairan yang diklasifikasikan isotonis mempunyai osmolalitas total yang mendekati cairan ekstraseluler dan tidak menyebabkan sel darah merah mengkerut atau membengkak. Hal ini menunjukkan bahwa jenis cairan isotonis lebih aman digunakan karena osmolalitas totalnya hampir sama dengan osmolalitas darah (Smeltzer dan Bare, 2002).

\section{b. Lokasi Pemasangan Infus}

Pada vena yang lebih besar dan sedikit cabang akan memudahkan dalam pemasangan cairan infus, menghindari resiko pecahnya pembuluh darah dan trauma/injury. Trauma/injurypada pemasangan infus bisa dilakukan dengan cara memilihvena yang besar dan lurus sesuai denganukuran jarum. Vena tangan lebih baik dari pada vena lengan karena bila terjadi sesuatu dapat di pindahkan ke lengan dan vena lengan lebih baik dari pada vena kaki dan paha karena pemasangan divena kaki dan paha lebih berisiko terjadinya inflamasi/ flebitis (Rohani, 2010). Dan, insersi di vena dorsalis lebih besar risiko terjadi flebitis dibandingkan dengan insersi kateter intravena (canul infus) di vena ventralis (forearm). (Maryunani, 2019)

Penelitian ini menunjukkan sebagian besar lokasi pemasangan infus responden yang mengalami flebitis yaitu pada vena dorsalis (vena metakarpal). Karena letak vena metakarpal berada di area tangan yang sering digerakkan dan mempunyai ukuran yang kecil, serta posisinya yang tidak lurus memungkinkan terjadinya gesekan pada dinding vena dengan kateter intravena. Namun data juga menunjukkan terdapat 2 responden dengan infus terpasang pada vena ventralis (vena sefalika) mengalami flebitis dan 11 responden dengan infus terpasang pada vena metakarpal tidak mengalami flebitis. Hal ini menunjukkan bahwa masih ada faktor-faktor lain yang dapat menyebabkan flebitis selain lokasi pemasangan infus, seperti lama waktu pemasangan infus, teknik insersi, obat parenteral, bahan kateter intravena dan sterilitas perawat.

\section{c. Hubungan Jenis Cairan Infus dengan Kejadian Flebitis}

Kejadian flebitis ditandai dengan adanya thrombus yang terdapat di dinding vena. Adanya thrombus meningkat di usia lebih dari 40 tahun, sehingga usia dianggap faktor resiko terjadinya thrombus. Keadaan hiperkoagulasi

Marlina Silviawaty ${ }^{1}$, Dian Utama Pratiwi Putri ${ }^{2}$

${ }^{1}$ Mahasiswa Prodi Magister Kesehatan Masyarakat UMI. Email : silviawatymarlina@gmail.com

${ }^{2}$ Dosen Prodi Magister Kesehatan Masyarakat UMI. Email : dian@umitra.ac.id 
meningkat berbanding lurus dengan bertambahnya usia yang disebabkan oleh peningkatan aktivasi koagulasi dan faktor degenerasi sel-sel tubuh. Flebitis bisa disebabkan karena adanya kontaminasi mikroba melalui titik akses ke sirkulasi dalam periode tertentu. Penggantian balutan yang jarang dan tidak teratur mengakibatkan kurangnya observasi pada lokasi pemasangan dan pemutusan perkembangbiakan kuman terjadi lebih lama sehingga kuman semakin berkurang, sedangkan penggunaan balutan yang transparan mudah untuk dilakukan pengawasan tanpa harus memanipulasinya. Penggunaan balutan konvensional masih bisa dilakukan, tetapi kassa steril harus diganti tiap 24 jam.

Pemberian cairan intravena adalah pemberian sejumlah cairan ke dalam tubuh masuk ke pembuluh darah vena untuk memperbaiki atau mencegah gangguan cairan dan elektrolit, darah, maupun nutrisi. Pemberian cairan intravena disesuaikan dengan kondisi kehilangan cairan pada pasien, seberapa besar cairan tubuh yang hilang. Pemberian cairan intravena merupakan salah satu tindakan invasif yang dilakukan tenaga kesehatan. Berdasarkan hasil penelitian didapatkan hasil bahwaresponden yang mengalami flebitis dengan cairan hipertonik sebanyak 13 orang (54\%) dan isotonic sebanyak 7 orang $(0 \%)$, dengan pengaruh bermakna yaitu $p$ value $=0,000$. Hal ini menyatakan terdapat hubungan antara cairan dengan kejadian flebitis.

Data penelitian ini didukung oleh pernyataanPotter dan Perry (2010), yang menyatakan bahwa cairan yang bersifat hipertonis memiliki osmolaritas yang lebih tinggi dibandingkan serum, sehingga menarik cairan dan elektrolit dari jaringan dan sel ke dalam pembuluh darah, misalnya: Dextrose $5 \%, \mathrm{NaCl}$ 45\% hipertonik, Dextrose 5\%+RingerLactate dan Manitol. Larutanlarutan ini menarik air dari kompartemen intraseluler ke ekstraseluler dan menyebabkan selsel mengkerut. Apabila diberikan dengan cepat dan dalam jumlah besar dapat menyebabkan kelebihan volume ekstraseluler dan mencetuskan kelebihan cairan sirkulatori dan dehidrasi.

Osmolalitas dapat diartikan sebagai konsentrasi sebuah larutan atau jumlah partikel yang larut dalam suatu larutan. Pada orang sehat konsentrasi plasma manusia adalah $285 \pm 10 \mathrm{mOsm} / \mathrm{kg} \mathrm{H} 2 \mathrm{O}$. Larutan sering dikategorikan sebagai larutan isotonik, hipotonik atau hipertonik, sesuai dengan osmolalitas total larutan tersebut dibanding dengan osmolalitas plasma. Larutan isotonik adalah larutan yang memiliki osmolalitas total sebesar 280-310 $\mathrm{mOsm} / \mathrm{L}$, larutan yang memliki osmolalitas kurang dari itu disebut hipotonik, sedangkan yang melebihi disebut larutan hipertonik. Tonisitas suatu larutan tidak hanya berpengaruh terhadap status fisik klien akan tetapi juga berpengaruh terhadap tunika intima pembuluh darah.

Dinding tunika intima akan mengalami trauma pada pemberian larutan hiperosmoler yang mempunyai osmolalitas lebih dari $600 \mathrm{mOsm} / \mathrm{L}$. Terlebih lagi pada saat pemberian dengan tetesan cepat pada pembuluh vena yang kecil. Cairan isotonic akan menjadi lebih hiperosmoler apabila ditambah dengan obat, elektrolit maupun nutrisi. Hasil penelitian ini didukung oleh penelitian Asrin,

Marlina Silviawaty ${ }^{1}$, Dian Utama Pratiwi Putri ${ }^{2}$

${ }^{1}$ Mahasiswa Prodi Magister Kesehatan Masyarakat UMI. Email : silviawatymarlina@gmail.com

${ }^{2}$ Dosen Prodi Magister Kesehatan Masyarakat UMI. Email : dian@umitra.ac.id 
Triyanti dan Upoyo tentang analisis faktor-faktor yang berpengaruh terhadap kejadian flebitis di RSUD Purbalingga, yang menyatakan bahwa cairan intravena yang diberikan merupakan salah satu penyebab terjadinya flebitis. Hal ini terjadi akibat cairan tersebut masuk sel endotelial sehingga terjadi ruptur. Iritasi dapat juga terjadi ketika cairan hipotonik seperti $\mathrm{NaCl}$ 0,45\% dicampurkan dengan air yang dimasukan dalam terapi intravena. Cairan hipertonik seperti D5\% dalam $\mathrm{NaCl}$ dan D5\% dalam RL dapat menyebabkan flebitis dengan sel endotelial terjadi kerusakan yaitu membran pembuluh darah menyusut dan terbuka. Kedua cairan (hipotonik dan hipertonik) dapat mengakibatkan iritasi pada pembuluh darah.

Berdasarkan informasi yang diperoleh dari data asuhan keperawatan dalam lembar catatan infus parenteral di rekam medis pasien di RS DKT Bandar Lampung, menunjukkan bahwa monitoring penggunaan cairan infus hipertonik oleh petugas kesehatan masih belum seragam dalam pelaksanaannya, berdasarkan SPO (Standar Prosedur Operasional) rumah sakit.

\section{d. Hubungan Lokasi Pemasangan Infus dengan Kejadian Flebitis} Hasil uji chi-square diperoleh $p v=0,002<0,05$. Berarti ada hubungan signifikan antara lokasi pemasangan infus dengan kejadian flebitis di Rumah Sakit DKT Bandar Lampung Tahun 2020. Diperoleh nilai $\quad \mathrm{OR}=3,5 \quad(1,6-7,8) \quad$ yang menunjukkan bahwa pasien yang lokasi pemasangan infusnya berisiko lebih berpeluang mengalami kejadian flebitis 3 kali dibandingkan dengan pasien lokasi pemasangan infusnya tidak berisiko.

Hasil penelitian ini sejalan dengan penelitian Suswitha (2019)yang membuktikan ada hubungan antara umur dengan kejadian flebitis dengan nilai $p=$ 0,042 . Ada hubungan antara ukuran kanula dengan kejadian flebitis dengan nilai $\mathrm{p}=0,013$. Ada hubungan antara lokasi pemasangan infus dengan kejadian flebitis dengan nilai $\mathrm{p}=0,040$. Ada hubungan antara lama pemasangan kanula dengan nilai $p$ value $=0,025$.

Ukuran vena sefalika yang besar dan lurus lebih dominan dipilih sebagai lokasi pemasangan infus dibandingkan vena metakarpal yang berukuran kecil dan tidak lurus. Selain itu pada orang dewasa bagian metakarpal sering digunakan untuk beraktifitas sehingga resikoterjadi injuryatau flebitis lebih besar. Penelitian Yasir (2014) menyatakan bahwa ada hubungan yang signifikan antara lokasi pemasangan infus dengan kejadian flebitis. Nurjanah (2004) menyatakan bahwa lokasi atau penempatan kateter intravena pada area fleksi lebih sering menimbulkan kejadian flebitis, oleh karena saat ekstremitas digerakkan kateter yang terpasang ikut bergerak dan menyebabkan trauma pada dinding vena. Pemilihan vena yang terlalu dekat dengan pergelangan tangan yang memudahkan untuk terjadinya aliran balik balik darah sehingga terjadiflebitis. Menurut Potter dan Perry (2010) bahwa posisiekstremitas yang berubah, khususnya pada pergelangan tangan atau siku dapat mengurangi kecepatan aliran infus dan mempengaruhi aliran dalam darah.

Marlina Silviawaty ${ }^{1}$, Dian Utama Pratiwi Putri ${ }^{2}$

${ }^{1}$ Mahasiswa Prodi Magister Kesehatan Masyarakat UMI. Email : silviawatymarlina@gmail.com

${ }^{2}$ Dosen Prodi Magister Kesehatan Masyarakat UMI. Email : dian@umitra.ac.id 
Pemasangan infus pada vena sefalika lebih baik digunakan.

\section{Kesimpulan dan Saran}

1. Distribusi frekuensi kelompok kasus (mengalami flebitis) pada penggunaan cairan infus berisiko adalah (40,0\%) dan lokasi pemasangan berisiko $(65,5 \%)$

2. Ada hubungan signifikan antara jenis cairan infus dengan kejadian flebitis di Rumah Sakit DKT Bandar Lampung tahun 2020. ( $p v=0,000<0,05 ; O R=8,5)$

3. Ada hubungan signifikan antara lokasi pemasangan infus dengan kejadian flebitis di Rumah Sakit DKT Bandar Lampung tahun 2020. $(p v=0,002<0,05 ; O R=3,5)$

\section{Saran}

Bagi pihak rumah sakit, agar dapat menyempurnakan SPO tentang prosedur pemberian cairan infus dan monitoring penggunaannya, sehingga diperoleh pelaksaanaan pemberian cairan infus dan monitoring yang seragam oleh seluruh perawat maupun dokter di rumah sakit, dengan harapan angka flebitis dapat diturunkan, dan mutu pelayanan rumah sakitdapat lebih meningkat.

\section{DAFTAR PUSTAKA}

Akbar, N. M. F. H. (2018). Pengaruh Karakteristik Pasien Yang Terpasang Kateter Intravena Terhadap Kejadian Flebitis. Jurnal Berkala Epidemiologi Volume 6 Nomor 1 (2018) 1-8 DOI: $10.20473 /$ jbe.v6i12018. 1-8 p-ISSN: 2301-7171 ; eISSN: 2541-092X

Black, J.M dan Hawk, J.H. (2014). Keperawatan Medikal Bedah; Manajemen Klinis untuk Hasil yang Diharapkan. Jakarta. Elseiver

Elvina., Erna. K. (2014). FaktorFaktor Yang Berhubungan Dengan Kejadian Flebitis Di Rsud Labuang Baji Makassar. Jurnal Ilmiah Kesehatan Diagnosis Volume 5 Nomor 1 Tahun 2014. ISSN : 2302-1721

Herlina, N. (2015). Hubungan kepatuhan SPO pemasangan infus dengan kejadian pblebitis di RSUD A. Wahab Sjahranie Samarinda tahun 2015. Jurnal Ilmu Kesehatan Vol.6 No 1

Haskas. Y. (2014). Faktor Yang Berhubungan Dengan Kejadian Phlebitis Diruang Perawatan Interna Rumah Sakit Umum Daerah Daya. Jurnal IImiah Kesehatan Diagnosis Volume 4 Nomor 4 Tahun 2014. ISSN : 2302-1721

Istiroha., Erfatunafiah. H. (2017). Faktor Lama Hari Pemasangan Infus tidak Berhubungan Dengan Kejadian Flebitis. Jurnal Of Ners Community Vol. $8 \quad$ No. 2 http://journal.unigres.ac.id/i ndex.php/JNC/article/view/4 O6Diakses tanggal 30 Januari 2020.

Kemenkes. (2017). Peraturan Menteri Kesehatan Republik IndonesiaNomor 27 Tahun 2017 Tentang Pedoman Pencegahan Dan Pengendalian Infeksi di Fasilitas Pelayanan Kesehatan. Kemkes Jakarta.

Kemenkes, (2017). Diagnosis, Klasifikasi, Pencegahan,

Marlina Silviawaty ${ }^{1}$, Dian Utama Pratiwi Putri ${ }^{2}$

${ }^{1}$ Mahasiswa Prodi Magister Kesehatan Masyarakat UMI. Email : silviawatymarlina@gmail.com

${ }^{2}$ Dosen Prodi Magister Kesehatan Masyarakat UMI. Email : dian@umitra.ac.id 
Terapi Penyakit Ginjal Kronis Direktorat P2PTM. http://p2ptm.kemkes.go.id/k egiatan-p2ptm/pusat-

/diagnosis-klasifikasi-

pencegahan-terapi-penyakitginjal-kronis

Lee. (2019). Model Flebitis Terkait Dengan kateter Intravena Perifer Pasien Rawat Inap Orthopedi

Lestari D. D., Ismanto A. Y., Malara Reginus T. (2016). Hubungan Jenis Cairan dan Lokasi Pemasangan Infus dengan kejadian flebitis pada pasien rawat inap di RSU Pancaran Kasih GMIM Manado. e journal keperawatan (e-Kp) Vol. 4 No. 1

https://ejournal.unsrat.ac.id /index.php/jkp/article/view/ 12009Diakses tanggal 30 Januari 2020.

Maryunani, A. (2019). Best Practice Phlebitis dan Komplikasi Lainnya; Pencegahan penanganan dan Perawatan Luka Terkait Pemberian Terapi Infus dan Intravena dalam Program PPI di Fasilitas Pelayanan Kesehatan. In Media Jakarta

Nursalam, (2014). Konsep dan Penerapan Metode Penelitian Keperawatan. Jakarta Salemba Medika

Potter\&Perry, (2010). Fundamental Of Nursing 7 th Ed. Canada: Elsavier.

Pujasari H. \& Sumarwati, M. (2012). Angka kejadian plebitis dan tingkat keparahannya di ruang penyakit dalam di sebuah rumah sakit di Jakarta. Jurnal Keperawatan Indonesia, 6(1), 1-5

Rahmawati., Sumiati S., Aries A, Desy. A. W. (2019). Faktorfaktor yang Berhubungan dengan Kejadian Plebitis Jurnal Medika Karya Ilmiah Kesehatan Vol 4, No.2. 2019 ISSN : 2654-945X

Rizky. W., (2016). Analisis faktor yang berhubungan dengan kejadian plebitis pada pasien yang terpasang kateter intravena di ruang bedah rumah sakit Ar. Bunda Prabumulih. Journal Ners And Midwifery Indonesia, 4(2), 102108,

Rohani., Hingawati. S. (2010). Panduan Praktik Keperawatan Nasokomial. PT Citra Aji Parama: Yogyakarta

Sjamsuhidajat. (2013). Buku Ajar Ilmu Bedah. Edisi 3. Jakarta: EGC

Salma. (2018). Hubungan Frekuensi Kateter Intravena Perifer Dengan Flebitis Dan Faktor Risiko Terkait

Supardi. (2013). Aplikasi Statistika dalam Penelitian Konsep Statistika yang Lebih. Komprehensif. Jakarta: Change Publication

Sugiyono. (2015). Metode Penelitian Pendidikan (Pendekatan Kuantitatif Kualitatif dan R\&D) Bandung. Alfabeta

Marlina Silviawaty ${ }^{1}$, Dian Utama Pratiwi Putri ${ }^{2}$

${ }^{1}$ Mahasiswa Prodi Magister Kesehatan Masyarakat UMI. Email : silviawatymarlina@gmail.com

${ }^{2}$ Dosen Prodi Magister Kesehatan Masyarakat UMI. Email : dian@umitra.ac.id 
Sugiyono. (2012). Metode Penelitian Kuantitatif Kualitatif dan R\&D. Bandung. Alfabeta

Terry. C.L dan Weaver, A, (2013). Keperawatan Kritis Demystified. Jakarta Rapha Publishing

Tosepu. R. (2016). Epidemiologi Lingkungan, Teori dan Aplikasi. Pertama. Jakarta: Bumi Medika.

Widiyanto. (2012). Faktor-faktor resiko yangmendukung kejadianplebitis di Sumah SakitCipto MangunkusumoJakarta.
Widoyono. (2011). Penyakit Tropis: Epidemiologi, Penularan, Pencegahan, dan. Pemberantasannya. Jakarta: Erlangga.

Wibowo, A. (2014). Metodologi Panelitian Praktis Bidang Kesehatan. Jakarta. Rajagrafindo Perkasa

Yuda. (2011). Infus Cairan Intravena (Macam-Macam Cairan Infus); Diakses $16 \quad$ April 2020.http: / /dokteryudabedah .com/infus-cairanintravenamacam-macamcairan-infus/ 